\title{
Decision Making Processes for a Patient with Cardiac Pacemaker Admitted to the Accident and Emergency Undergoing Magnetic Resonance Imaging - A Case Study
}

\author{
F. P. RADITYA
}

\begin{abstract}
This case study aims to apply the processes of decision-making for magnetic resonance imaging (MRI) as a diagnostic examination for a patient with cardiac pacemaker admitted to a private hospital in the capital of Indonesia. It also aims to examine and evaluate the case of a 53-year-old mother who had a heart abnormality that has a pacemaker for one year and was diagnosed to do an MRI examination because of a suspected tumor on the wrist area.

The three basic models of decision-making - the descriptive, prescriptive and normative were applied. The prescriptive used the information processing theory, while the normative used decision trees as decision options and lastly, the descriptive used intuition and pattern recognition.

Dominantly, the prescriptive model for decision-making is more appropriate for this case. The descriptive decision-making model, using intuition however, helped in supporting the intuitive hypothesis. Lastly, the normative model of decision-making played an important role but was not likely effective.
\end{abstract}

Key words: Decision-making processes; case study; MRI with pacemaker; A\&E

This case study aims to apply the processes of decision making for magnetic resonance imaging (MRI) as a diagnostic examination for a patient with cardiac pacemaker admitted to a private hospital in the capital of Indonesia. It also aims to examine and evaluate the case of a 53-year-old mother who has a heart abnormality with pacemaker for one year and should be doing an MRI examination because of a suspected tumor on the wrist area.

\section{BACKGROUND OF THE STUDY}

An MRI is generally contraindicated for patients with pacemaker or implantable cardiac defibrillator (ICD), because of the risk of life-threatening interference with the device (Bovenschulte et al. 2012). However, compared with computerized tomography scanning and ultrasonography, only the modalities of an MRI is capable to show the soft tissues and joint fluids hence can easily see abnormalities (Kartawiguna 2014). This is because MRI images can capture process-based location and the atomic number of cells (Kartawiguna 2014).

Based on surveys which have been reported, more than 650000 patients every year are installing a new pacemaker implantation worldwide (Figure 1). Where it contained $50 \%$ to $75 \%$ of these patients, it developed indications for MRI during their devices and showed that every year, approximately 200000 patients with pacemakers or ICDs, MRI was rejected (Roguin et al. 2008).

Academy Technical Radio-diagnostic and Radiotherapy Nusantara, Indonesia

* Corresponding author (e-mail: radityafaradina@gmail.com) 


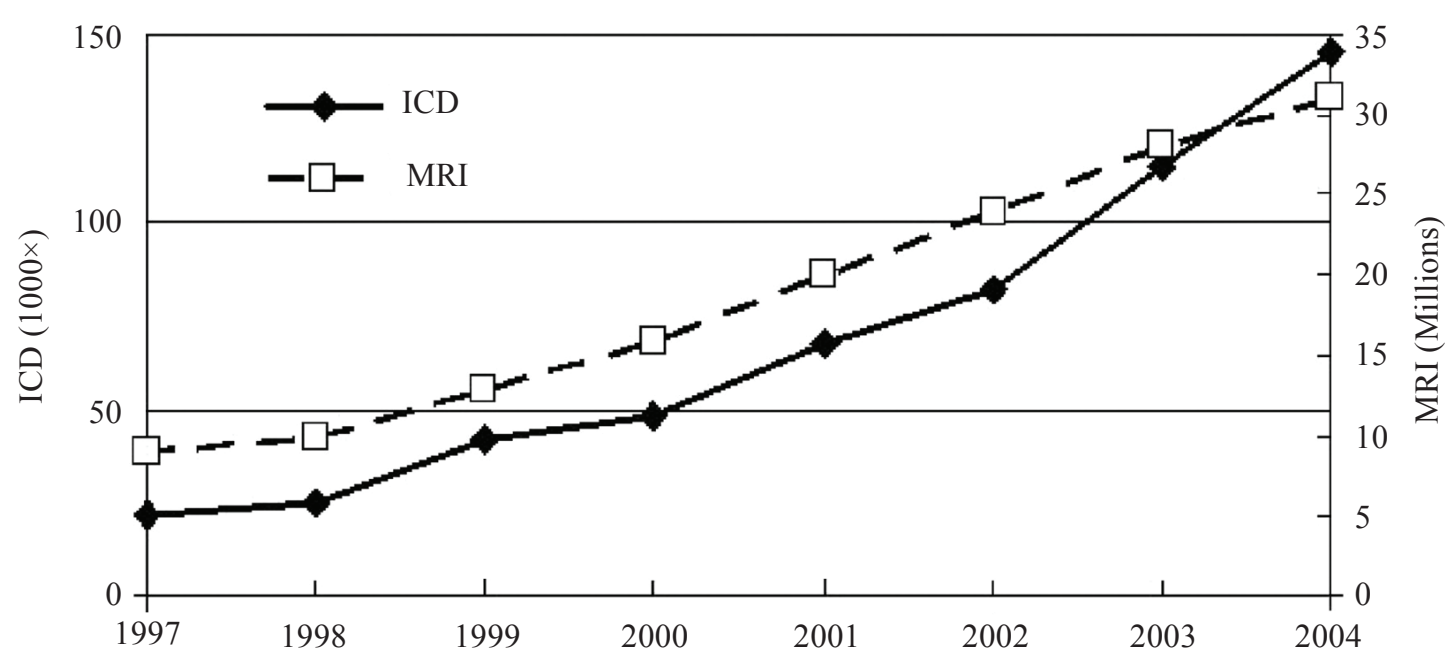

Figure 1. Number of annual MRI scans and of newly implanted ICDs (Roguin et al. 2008).

There are potential effects of MRI to cardiac pacemakers and ICDs that were considered to be absolutely contraindicated due to the following potential issues (Shellock et al. 1999): (1) Movement and/or vibration of the pulse generator or lead(s); (2) Temporary or permanent modification of the function (i.e. damage) of the device; (3) Inappropriate sensing, triggering, or activation of the device; (4) Excessive heating of the leads; (5) Induced currents in the leads and (6) Electromagnetic interference.

In Indonesia, with the increasing prevalence of implantable devices and the increasing utility and availability of MRIs, there are many occasions where there is a great medical need to perform MRI in patients with an ICD and pacemakers. As a result, these have led to the development of the guidelines for scanning patients with cardiac pacemakers / ICDs (FDA Recommandation).

\section{THE CASE}

A 53-year-old mother admitted to the accident and emergency (A\&E) department with great pain and swelling in the wrist area without trauma cases. The author and the A\&E department physician-in-charge intuitively suspected an abscess. Radiologic X-ray examination of the wrist joint was conducted. However, the results were not clear showed in the X-ray. After analyzing the medical history of the patient, it was found that the patient had installed a pacemaker in her heart because of an arrhythmia a year ago.

Clinical specialists concerning heart and pacemakers say that MRI and other investigations for purposes of advanced diagnostic examination might be contraindicated. However, A\&E physician-in-charge instructed the author (as the radiologist), that soft tissues and joint fluids from the patient's wrist needed to be visualized using an MRI.

The author identified possibilities of giving options by looking at the history and the operation techniques done on the patient. The author also explained to the patient the American Society for Testing and Materials International (ASTM) recommends grouping of pacemaker patients into three categories, which are: Safe magnetic resonance (MR), the 
MR compatible / MR and the MR conditional prohibited / MR unsafe (ASTM International 2003).

Having investigated by interview that the patient was using Medtronic pacemaker with a new generation of materials, the MR categorised as 'conditional' was hence advised by the hospital as a norm for doing an alternative to MRIs. Figure 2 shows the decision tree as the decision option for the patient. These options are used for patients with cardiac pacemaker who will undergo MRI (ASTM International 2003).

The relatives' decision (Say \& Thomson 2003) are also important to be considered, therefore the A\&E physician-in-charge presents probabilities shown in Figure 2, to the relatives during the discussion.

The patient was encouraged by the A\&E physician-in-charge and clinical experts to take the MRI conditionally. According to clinical guidelines, there are altered physiologies to be considered when patients are brought into the radiology departments that have pacemakers or ICDs. Primarily it may lead to radiation frequency (RF) interference, shifting location of pacemakers, and thermal effect (Shellock et al. 1999).

However, in the category of the MRI compatible/MR conditional pacemakers, these could contain risks that could be fatal for the patient. The development and implementation of cardiac MR conditional devices would continue to require the expertise and collaboration of multiple disciplines and would need to prove safe, effective, and cost effective patient care.

Figure 3 explains the altered physiology of patients with pacemakers undergoing MRIs and analyzes the hidden effects after doing the MRI examination.

A risk-benefit ratio must be established before the MRI examination procedure is carried out (University of California San Francisco Guidelines 2015).

\section{Upon Entering the Radiology Unit}

The author intuitively perceived the main risks of MRIs that was conceived of a large magnetic force with magnetic attraction that was extremely large, in which attractive force is the potential to affect the projectile and change the location of the patient's pacemaker (Brown \& Semelka 2003).

The author adjusted the field strength to 1.5 tesla (Shellock et al. 2004).

Figure 4 shows the resonant frequency in megahertz $(\mathrm{MHz})$ as the formula that was used by the author, referred to as Larmor Frequency (Kartawiguna 2015).

If it uses magnetic field strength of 1.5 tesla, then the value of the RF must only be at 63.9 $\mathrm{MHz}$ (Kartawiguna 2015). The greater the RF

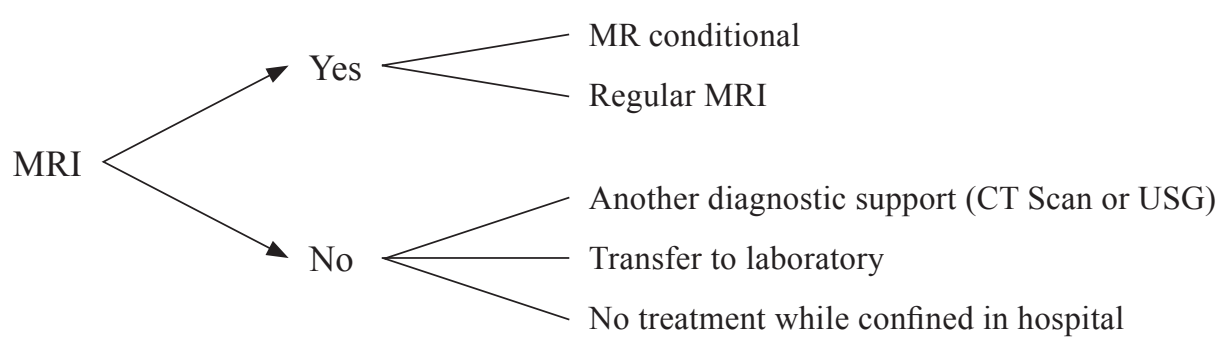

Figure 2. The decision tree divided into probabilities. 


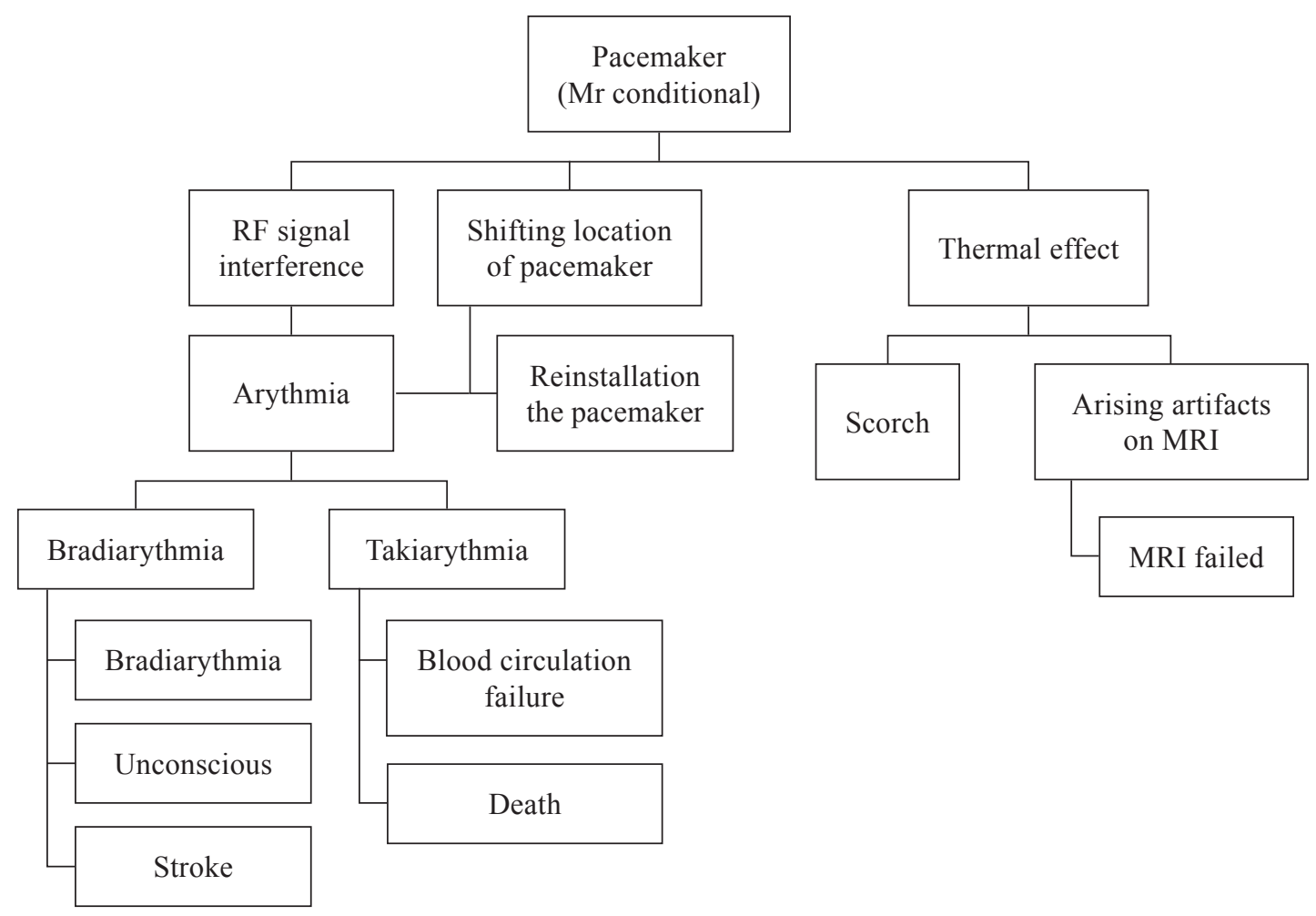

Figure 3. Altered physiologies of patients with pacemakers undergoing conditional MRIs.

$$
\omega_{0}=\gamma \mathrm{B}_{0}
$$

$\omega_{0}$ is Larmor frequency ( $\mathrm{MHz}$ tesla)

$\gamma$ is gyromagnetic constant (MHz tesla 1$)$

$\mathrm{B}_{0}$ is magnetic field strength (Tesla)

Figure 4. Larmor frequency.

used will give a bad effect on the patient with pacemaker (Götte et al. 2010).

However, by using a magnetic field that is less than 1.5 tesla, will require a longer scanning time (Roguin et al. 2004). This is because the scanning time is inversely proportional to the resonant frequency (Brown \& Semelka 2003). The author must explain to the patient that she would need to be scanned more than $30 \mathrm{~min}$ inside the MRI scanning device.

The procedural management of MRI for patients with pacemakers or ICDs is primarily divided into (1) protocols and examination procedure; (2) procedural management setting and measures, and (3) planning and conduct of procedures. 
Performing these skills found on Table 1 was important since the heating effect occured during MRI. The energy heap the RF deposits on body tissues (Bovenschulte et al. 2012). This results in warming of the endo-/myocardium that may lead to edema formation or even scarring, which in turn can result in alteration of the pacing thresholds (Bovenschulte et al. 2012). In addition, the Specific Absorption Rate (SAR) is a reference to the body's ability to neutralize energy (Bovenschulte et al. 2012). The author was needed to measure the energy arising from the MRI, and on the type and position of the electrode of the pacemaker.

The increase in temperature approached those used in thermos-ablative procedures, so the potential for harm was considerable; this can be expressed, for instance, in alterations of the pacing threshold (Nazarian et al. 2011). The amount of the SAR recommended a $<2.0 \mathrm{~kg}$ to an average SAR of $<3.2 \mathrm{~kg}$ (Bovenschulte et al. 2012).

The MRI scan was conducted by an attending radiologist, and monitored by a cardiologist and an electro-physiologist. The patient was also monitored by the author continuously during the MRI (e.g. blood pressure, pulse rate, oxygen saturation, and ECG).

During the examination, the patient was monitored using electrocardiography and pulse oximetry (Nazarian et al. 2011). The author also maintained visual and verbal contact on the patient throughout the MRI procedure. Figure 5 shows the electrocardiographic result with evidence of a captured pacemaker.

The author also instructed the patient to verbally communicate in case of any

Table 1. Procedural management (The position paper of the European Society of Cardiology 2008)

\begin{tabular}{|c|c|c|}
\hline \multicolumn{3}{|c|}{ Procedural management of MRI in patient with a pacemakers or ICD } \\
\hline $\begin{array}{l}\text { MRI protocols and } \\
\text { examination procedure }\end{array}$ & $\begin{array}{l}\mathrm{PM} / \mathrm{ICD} \text { settings } \\
\text { and measures }\end{array}$ & $\begin{array}{l}\text { Planning and conduct } \\
\text { of procedure }\end{array}$ \\
\hline $\begin{array}{l}\text { - Restrict scanner field } \\
\text { strength to } \leq 1.5 \mathrm{t} \\
\text { - Keep SAR of } \\
\text { sequences used as low } \\
\text { as possible, no SAR > } \\
2 \mathrm{~W} / \mathrm{Kg} \\
\text { - Plan examination } \\
\text { precisely in advances } \\
\text { as possible } \\
\text { - If possible, do not use } \\
\text { surface coils }\end{array}$ & $\begin{array}{l}\text { - Perform MRI no less than 4-8 } \\
\text { weeks after implantation } \\
\text { - Inspect device throroughly } \\
\text { before and after MRI } \\
\text { - Continue monitoring after } \\
\text { MRI until completion of } \\
\text { reprogramming and testing } \\
\text { (threshold values of sensing } \\
\text { and pacing) } \\
\text { - Switch PM to "off" during MRI } \\
\text { (sensing only) or to "output" } \\
\text { below the pacing threshold } \\
\text { - ICD treatment off } \\
\text { - Non-PM-dependent patients on } \\
\text { asynchronous mode } \\
\text { - Check ICD/PM parameters } \\
\text { (pacing threshold etc.) after } 1 \\
\text { month and } 3 \text { months }\end{array}$ & $\begin{array}{l}\text { - Perform the examination at } \\
\text { a well equipped centre with } \\
\text { experienced staff } \\
\text { - Obtain cardiological } \\
\text { assessment of PM (non) } \\
\text { dependence, if patient is PM } \\
\text { dependent, consider re- } \\
\text { evaluating the indications } \\
\text { - Radiologist and cardiologist } \\
\text { should be present during the } \\
\text { examination, with continuous } \\
\text { monitoring (ECG, blood } \\
\text { pressure, pulse eximetry) } \\
\text { - Programming of the PM/ICD } \\
\text { in the MRI suite should be } \\
\text { possible } \\
\text { - A defibrillator with PM } \\
\text { capability should be available } \\
\text { in the MRI suite }\end{array}$ \\
\hline
\end{tabular}


complications that might arise such as headache, nausea and/or vomiting or to alert the MR system's "push-button" for any unusual heart sensations or palpitations.

As a safety measure, the author also prepared advanced cardiopulmonary resuscitation equipment along the MRI hallway, along with an external cardioverter or defibrillator and the programmer of the pacing device (Nazarian et al. 2011).

After the scan, a systematic questionnaire was provided to the patient to inquire regarding pain, sensation of movement of the pacemaker device, heat felt on the chest, or any other discomfort. In addition, the duration of the MRI was noted and the A\&E physician-in-charge assessed the patient of any untoward signs and symptoms.

After the examination an electrophysiologists checked the pacemaker performance. The result showed no changes on the pacemaker device, but the patient still must be followed-up within 1 to 3 months.

The author however, was also aware about the procedural management as a clinical guideline for the patient undergoing MRI comprising three basic components:

(1) The technical requirements for the MR scanner and the selection and planning of examination sequences;

(2) The technical handling of the pacemaker device before, during, and after examination; and
(3) The basic planning and execution of the examination, taking all appropriate (emergency) precautions to minimize the risk for the patient.

\section{METHODOLOGY}

This section examines and evaluates how the three basic models of decision-making the descriptive, prescriptive and normative (Table 2) - were applied.

\section{Prescriptive Decision-making Model}

Information processing theory. Its characteristic uses framework or information and facilitating more effective decision making as its advantage (Bell et al. 1995; Harrison 1996).

The information processing theory (IPT) that the author used was the procedural management of MRI in patient with a pacemakers found on Table 1. The procedural management started with technical requirements for the MR scanner, selection and planning of examination sequences and ended with technical handling of the pacemaker device before, during, and after examination.

\section{Step One: Cue Acquisition}

Upon admission to the A\&E department, the patient was experiencing pain and swelling in the wrist. These were the cues that led to the instigation of having a regular X-ray of the wrist. However, another cue was found on the $\mathrm{X}$-ray results that the wrist did not have any

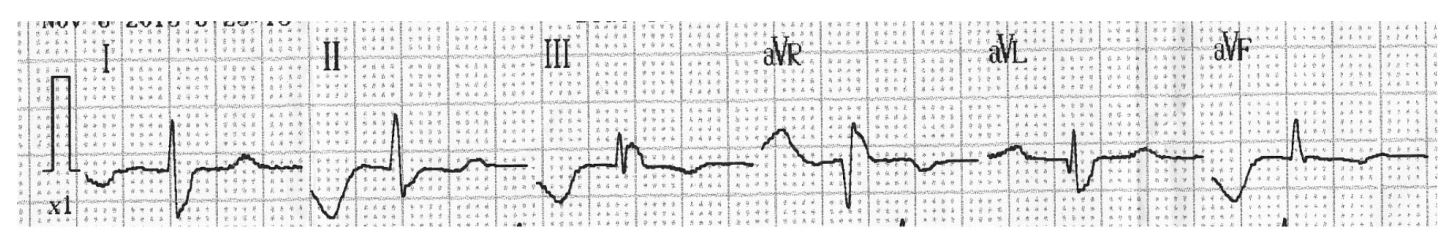

Figure 5. Patient electrocardiographic result with evidence of a captured pacemaker. 
Table 2. Summary of three decision-making models (Shaban 2005; Thompson \& Dowding 2002; Tanner et al. 1987; Offredy 1998; Dioso 2015)

\begin{tabular}{|c|c|}
\hline \multicolumn{2}{|r|}{ Normative model } \\
\hline Characteristics & Rational, logical, scientific, evidence-based decisions. \\
\hline Information sources & $\begin{array}{l}\text { Statistical analysis of large-scale experimental and survey research which is } \\
\text { representative of a target population where the findings can be applied. }\end{array}$ \\
\hline Examples & Decision trees as decision options. \\
\hline Advantages & $\begin{array}{l}\text { Enable decision-makers to predict and explain the outcomes of decisions. } \\
\text { Minimize judgment errors from "base rate neglect". }\end{array}$ \\
\hline \multicolumn{2}{|r|}{ Prescriptive model } \\
\hline Characteristics & Frameworks or guidelines designed to enhance specific decision tasks. \\
\hline Information sources & $\begin{array}{l}\text { Principles and findings of previous scientific research (associated with normative } \\
\text { models). }\end{array}$ \\
\hline Examples & Information Processing Theory. \\
\hline Advantage & Facilitating more effective decision-making. \\
\hline \multicolumn{2}{|r|}{ Descriptive model } \\
\hline Characteristics & $\begin{array}{l}\text { Understanding how individuals make judgments and decisions focusing on the } \\
\text { actual conditions, contexts, ecologies, and environments in which they are made. }\end{array}$ \\
\hline Information sources & $\begin{array}{l}\text { Observation, description and analysis of how decisions are made by managers } \\
\text { and professionals in relation to their day-to-day responsibilities. }\end{array}$ \\
\hline Examples & Intuition. \\
\hline Advantage & $\begin{array}{l}\text { Adequacy in supporting assumptions made about decision-making processes with } \\
\text { relevant examples from a suitable period of observation. }\end{array}$ \\
\hline
\end{tabular}

fractures or dislocations. That was why an MRI was hypothesized to be indicated.

\section{Step Two: Hypothesis Generation}

It was hypothesized that patients with pacemakers would not survive computerized tomography scanning; therefore, in order to visualize the soft tissues on the tumor found in her arm, an MRI was more likely to be indicated. It was also hypothesized that the patient would survive the MRI if precautions would be done using clinical guidelines.

The clinical guideline of the European Society of Cardiology (2008), primarily proposes classification of pacemakers and ICDs into three categories before conducting an
MRI: non-pacemaker-dependent patients (low risk); ICD patients (high risk); and pacemakerdependent patients (extremely high risk) (Table 3). The patient was classified as low risk.

Therefore, it was hypothesized that in order to survive the MRI, an external defibrillator should be available while conducting the procedure (Nazarian et al. 2011).

Another precaution was also hypothesized that in order to survive an MRI an RF wave exposure must be lesser than 1.5 tesla (Bovenschulte et al. 2012). This is because an RF takes place repeatedly during an MRI examination that collects enough echo signals to be processed into image data (Bovenschulte et al. 2012). In accordance with the Larmor law, 
where Larmor frequency will be affected by the strength of the static magnetic field, the greater the strength of MRI is used, the greater the RF wave is released therby cooking the pacemaker and its battery (Bovenschulte et al. 2012). In addition, it was hypothesized that an RF waves were emitted that would interfere with the signal transmission process of a pacemaker thus led to bradyarrhythmic or tachyarrhythmic.

\section{Step Three: Interpretation of Cues}

The interpreted electrocardiographic result (Figure 5) shows that the patient was positive to have a good functioning pacemaker and was recommended to have an MRI. It was also particularly important for the author to ponder how urgently MRI was indicated and whether there were feasible diagnostic alternatives. Other imaging procedures safer for patient with pacemaker such as ultrasonograms has been considered, but only MRI is more specific that can show soft tissue abnormalities of the patient's wrist (Bushberg et al. 2002).

\section{Step Four: Hypothesis Evaluation}

It was evaluated that there was a soft tissue tumor found on the wrist of the patient. In this step, it was also evaluated that the patient with cardiac pacemaker was made safe from magnetism. There are three factors relevant for the problematic interactions with pacemakers/
ICDs and their electrodes: the static magnetic field (mechanical effects), the transmitted thermal effects, and the changing magnetic gradients in spatial encoding (induction effects) (Henning et al. 2012). The proportion of magnetic metals in devices and electrodes of pacemakers are limited, however, not great enough to cause displacement of either device or electrode, that is why MRI is recommended (Roguin et al. 2004).

The pacemaker electrode leads function as an antenna, in which energy generated by variable magnetic fields is conducted to the adjacent tissue in the form of heat (Henning et al. 2012). This results in warming of the endo-/myocardium that may lead to edema formation or even scarring, which in turn can result in alteration of the pacing thresholds (Sommer T, Naehle CP, Yang A, et al. 2006).

The pacemaker device may be directly affected by electromagnetic interference (Shinbane et al. 2011). One factor is the activity of the reed switch. The standard parameters may not always suffice for effective stimulation in patients who need high initial energy (Shinbane et al. 2011). The main dangers are thus asystole from inhibition of pacing and induction of tachycardia by inadequate asynchronous pacing (Gimbel 2009). Figure 6 shows the ECG result from patient after MRI examination.

Table 3. Classification of patients according to the risk involved in performing MRI, when no other diagnostic procedure is indicated (The European Society of Cardiology 2008).

\begin{tabular}{|l|ll|}
\hline \multicolumn{2}{|c|}{ Population risk groups } \\
\hline $\begin{array}{l}\text { Group 1: } \\
\text { Extremely High Risk }\end{array}$ & $\begin{array}{l}\text { Pacemaker-dependent } \\
\text { patients }\end{array}$ & $\begin{array}{l}\text { Alternative means of cardiac stimulation } \\
\text { (transcutaneous electrodes, temporary sensors) } \\
\text { should be available }\end{array}$ \\
$\begin{array}{l}\text { Group 2: } \\
\text { High Risk }\end{array}$ & $\begin{array}{l}\text { External defibrillation apparatus should be } \\
\text { iCD patients (non- } \\
\text { pacemaker-dependent) }\end{array}$ & $\begin{array}{l}\text { available and emergency pacemaker operation } \\
\text { should be done }\end{array}$ \\
Group 3 : & $\begin{array}{l}\text { External defibrillation apparatus should be } \\
\text { available }\end{array}$ \\
Low risk & dependent patients & \\
\hline
\end{tabular}




\section{Normative Decision-making Model}

Patients' relatives were presented with options in a form of decision trees (Say \& Thomson 2003). The decision tree found in Figure 2 was used for this case based on the clinical guidelines in outlining options. However, the physicians still instigated that MRI be advised because the prescriptive decision-making process was the norm that is always done in the A\&E.

\section{Descriptive Decision-making Model}

Intuitively, as soon as the electrocardiographic results were released, the collaborating healthcare professionals descriptively decided that the patient must require other investigations for purposes of advanced diagnostics. Physicians are required to see and analyze the picture of the soft tissue and joint fluid from the patient's wrist.

In a descriptive decision-making, intuition (Offredy \& Meerabeau 2005) enumerates probabilities during a discussion. Probabilities are easier to use when collaborating with other experts to intuitively enumerate tasks to measure clinical reasoning (McAllister et al. 2009). In addition to Brien et al. (2011) and Benner and Tanner's (1987) study on how to trust an intuition, Hams (2000) also said that during discussions with the relatives and the clinical experts, patterns of previously experienced events must be intuitively considered in order to validate an intuition. Banning (2007) supported this method of decision-making as a role of learning from experiences.

Intuitions are done descriptively according to Banning (2007) by starting with an intuitive hypothesis and perception. Thereby X-ray was chosen at an early stage of consultation but from the X-ray result it was not visible suspicion disorders suffered by patients.

It is usually during the late stage of consultation where intuitive hypothesis generation is trusted (Dioso 2015). That is why the patient was decided to undergoing MRIs.

Banning (2007) said that this process of decision-making, as an intuitive perception is also done by recognizing patterns from past experiences. Figure 7 illustrates the process of trusting an intuition.

\section{DISCUSSION}

The prescriptive decision-making model was dominantly used in this case. The patient acquired the cues but the intuition also supported the IPT that the patient could be safe before, during and after an MRI. However, normative decision-making model was not completely used autonomously by the patient.

The patients are the key decision-makers (Lomas et al. 1989). However, if the patient was not completely knowledgeable of the possible disadvantages of an intervention, then

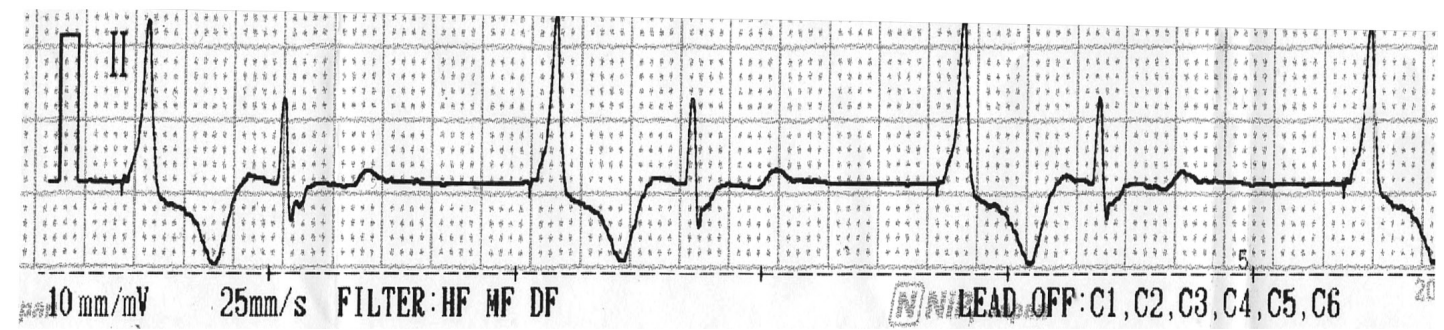

Figure 6. The ECG Result from the patient shows a regular rhythmic capture of the pacemaker. 
it is justified that the patient takes advices from healthcare experts (Lomas et al. 1989; Offredy \& Meerabeau 2005).

In this case study, the patient had chances to choose but it was also seen that there was no other radiologic diagnostic examination that might visualize the abscess intuitively hypothesized that it was found on the wrist of the patient.

\section{RECOMMENDATIONS}

MRI of PM/ICD places high demands on both personnel and apparatus, and should thus preferably be performed at wellequipped centres with experienced staff (FDA Recomandation 2015).

It is recommended that the patient with a pacemaker or ICDs should be subjected to MRI only when there is no alternative accurate radiologic diagnostic examination (UCSF Guideline 2015).

Recommendations for static magnetic field devices however must use the static magnetic field 1.5 to 3 tesla, which corresponds to 30000 -60000 times the strength of earth's magnetic field (Shinbane et al. 2011). MRI scanners are typically superconducting, thus, they were always attracting ferromagnetic object into the scanner. That is why the devices should be non-ferromagnetic or weakly ferromagnetic (most are) because it is the lowest field strength available to minimize ferromagnetic risk (Roguin et al. 2004).

Recommendations based on material, nonferromagnetic 'passive' implant (e.g. titanium, titanium alloy, nitinol) MRI should be used immediately after implantation or six weeks after implantation (Nazarian et al. 2011).

Recommendation based of the procedural management as a clinical guideline for patient undergoing MRI comprises: (1) The technical requirements for the MR scanner and the selection and planning of examination sequences; (2) The technical handling of the pacemaker before, during, and after examination, and (3) The basic planning and execution of the examination, taking all appropriate (emergency) precautions to minimize the risk for patient safety.

\section{CONCLUSION}

It is therefore concluded, that IPT used clinical guidelines in order to decide that MRI was the best option for the patient. Dominantly, the prescriptive model for decision-making was more appropriate for this case. The descriptive decision-making model however, helped in supporting the intuitive hypothesis that there was an abscess in the patient's wrist. Therefore, intuition made the decision-making easier.

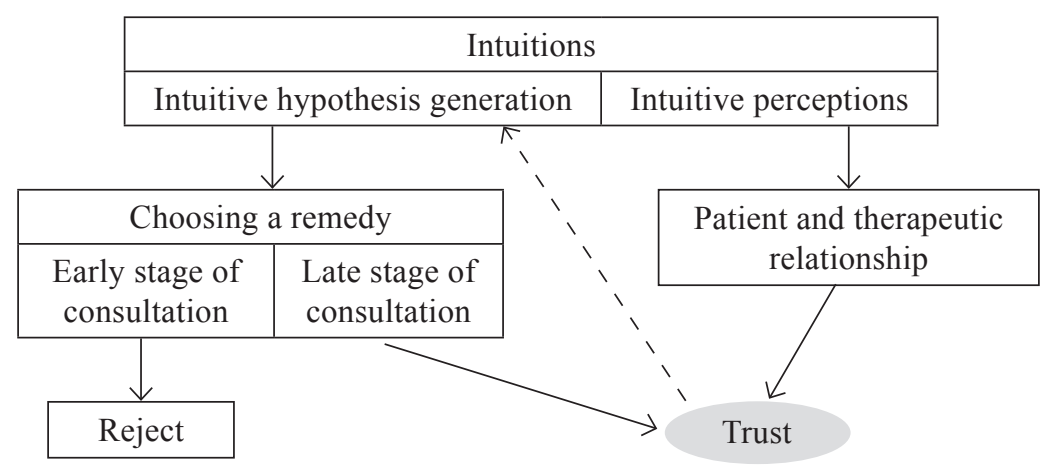

Figure 7. How to use an intuition (Dioso 2015). 
Lastly, the normative model of decision-making played an important role but was not likely effective since the patient was still relying on the physician's advice.

\section{ACKNOWLEDGEMENT}

The valuable assistance of Regidor III for the supervision of this study is much appreciated

\section{Date of submission: January 2016}

Date of acceptance: February 2016

\section{REFERENCES}

American Society for Testing and Materials 2003, 'Standard practice for marking medical devices and other items for safety in the magnetic resonance environment', ASTM International, F2503-05 (West Conshohocken, PA).

Banning, M 2007, 'A review of clinical decision making: models and current research', Journal of Clinical Nursing, vol. 17, no. 2, pp. 187-195.

Bell, DE, Raiffa, H \& Tversky, A 1995, 'Descriptive, normative and prescriptive interactions in decision making', in Decision-making, eds DE Bell, H Raiffa \& A Tversky, Cambridge University Press, Cambridge.

Bovenschulte, H, Schlüter-Brust, K \& Liebig T, et al. 2012, 'MRI in patients with pacemakers: overview and procedural management', Dtsch. Arztebl. Int., vol. 109. No. 15, pp. 270-275.

Brown, MA \& Semelka, RC 2003, MRI Basic Principles and Applications, 3rd edn, New York: Wiley-Liss Publication.

Bushberg, JT, Selbert, JA, Leidholdt, JE \& Boone, JM 2002, The essential physics of medical imaging, Lippincott Williams \& Wilkins, Philadelphia.

Dioso, R III 2015, 'Decision-making processes for a do-not-resuscitate poisoned pediatric patient admitted to the department of emergency and medical services. ASEAN Journal for Science and Technology for Development, vol. 15, no. 2, pp. 15-21.

Food and Drug Administration 2015, 'Manufacturer and user facility device experience database (MAUDE)', viewed 15 October $2015<$ http:// www.fda.gov/cdrh/maude.html $>$.
Gimbel, JR, Bailey, SM, Tchou, PJ, Ruggieri, PM \& Wilkoff, BL 2005, 'Strategies for the safe magnetic resonance imaging of pacemakerdependent patients', Pacing Clin Electrophysiol, vol. 28, pp. 1041-1046.

Gimbel, JR, Johnson, D, Levine, PA \& Wilkoff, BL 1996, 'Safe performance of magnetic resonance imaging on five patients with permanent cardiac pacemakers', Pacing Clin Electrophysiol, vol. 19, no. 6, pp. 913-919.

Götte, MJ, Rüssel, IK, de Roest, GJ, Germans, T, Veldkamp, RF \& Knaapen, $\mathrm{P}$ et al. 2010, 'Magnetic resonance imaging, pacemakers and implantable cardioverter-defibrillators: current situation and clinical perspective', Neth. Heart $J$., vol. 18, no. 1, pp. 31-37.

Henning, B, Schlüter-Brust, K \& Liebig, T et al. 2012, 'Deutsches Ärzteblatt International MRI in Patient with Pacemaker', Dutsch Arztebl. Int., vol. 109, no. 15, pp. 270-275.

Joint Commission on Accreditation of Healthcare Organizations 2007, 'Working together to improve MRI safety', The Joint Commission Perspectives on Patient Safety, vol. 7, no. 2, pp. $1-4 ; 8-12$.

Kanal, E \& Gimbel JR 2009, 'MR-conditional pacemakers (letter)', AJR Am. J. Roentgenol., vol. 198, no. 5, pp. W502-503.

Kartawiguna D 2015, Tomografi resonansi magnetik inti; teori dasar, pembentukkan gambar dan instrumentasi perangkat kerasnya, Graha Ilmu, Yogyakarta.

Lomas, J, Anderson, GM, Domnick-Pierre, K, Vayda, E, Enkin, MW \& Hannah, WJ 1989, Do Practice Guidelines Guide Practice?, New England Journal of Medicine, vol. 321, pp. 1306-1311.

Martin, ET, Coman, JA, Shellock, FG, Pulling, CC, Fair, R, Jenkins, K 2004, 'Magnetic resonance imaging and cardiac pacemaker safety at 1.5-tesla', J. Am. Coll. Cardiol., vol. 43, pp. 1315-1324.

Nazarian, S, Hansford, R \& Roguin, A et al. 2011, 'A prospective evaluation of a protocol for magnetic resonance imaging of patients with implanted cardiac devices', Ann. Intern. Med., vol. 155, no. 7, pp. 415-424.

Naehle, CP, Zeijlemaker, V \& Thomas, D et al. 2009, 'Evaluation of cumulative effects of MR imaging 
on pacemaker systems at 1.5 tesla', Pacing Clin. Electrophysiol., vol. 32, pp. 1526-1535.

Roguin, A, Schwitter, J \& Vahlhaus, C et al. 2008, 'Magnetic resonance imaging in individuals with cardiovascular implantable electronic devices', Europace, vol. 10, pp. 336-346.

Roguin, A, Zviman, MM, Meininger, GR, Rodrigues, ER, Dickfield, TM, Bluemke, DA et al. 2004, 'Modern pacemaker and implantable cardioverter/ defibrillator systems can be magnetic resonance imaging safe. In vitro and invivo assessment of safety and function at 1.5 t', Circulation, vol. 110, pp. 475-482.

Shaban, R 2005, 'Theories of clinical judgment and decision-making: a review of the theoretical literature', Journal of Emergency Primary Health Care, vol. 3, no. 1-2, pp. 1-10.

Shellock, FG et al. 1999, 'Cardiac pacemakers and implantable cardiac defibrillators are unaffected by operation of an extremity MR system', $A J R$ Am. J. Roentgenol., vol. 72, pp. 165-170.

Shinbane, JS, Colletti, PM \& Shellock, FG 2007, 'MR in patients with pacemakers and ICDs: Defining the issues', J. Cardiovasc. Magn. Reson., vol. 9, no. 1, pp. 5-13.

Sommer, T, Nachle, CP, Yang, A et al. 2006, 'Strategy for safe performanceof extrathoracic magnetic resonance imaging at 1.5 tesla in the presence of cardiac pacemakers in nonpacemaker-dependent patiens : a prospective study with 115 examinations', Circulation, vol. 114, no.12, pp. 1285-1292.

UCSF Department of Radiology \& Biomedical Imaging 2015, 'MRI safety policy of UCSF: MRI imaging of patients pacemakers and implantable cardioverter-defibrillator', viewed 15 October 2015, <http://www.radiology.ucsf.edu/patientcare $>$. 